\title{
Restless legs syndrome and quality of life in pregnant women
}

\author{
Pınar Akbaş ${ }^{1}$ \\ DS Şengül Yaman Sözbir²
}

\begin{abstract}
1. Gazi University Institute of Health Sciences, Emniyet Mah. Abant Sok. No: $10 / 2$ E Blok Kat:9 06500 Yenimahalle/Ankara, Turkey 2. Faculty of Health Sciences, Nursing Department Gazi University, Emniyet Mah. Muammer Yaşar Bostancı Cad. No:16, 06560, Beşevler/Ankara, Turkey
\end{abstract}

http://dx.doi.org/10.1590/1806-9282.65.5.618

\section{SUMMARY}

OBJECTIVE: In this study, we aimed to determine the extent of restless legs syndrome (RLS) in pregnant women and evaluate the relationship between the syndrome and quality of life.

METHODS: This is a cross-sectional descriptive study. A questionnaire developed by the researcher, the Short Form 36 (SF-36) Questionnaire to measure the quality of life, the International Restless Legs Syndrome Study Group (IRLSSG) Diagnostic Criteria for RLS and the Restless Legs Syndrome Rating Scale were applied to the women to collect the data. A total of 250 pregnant women were included in the study.

RESULTS: The mean age of the women was $28.11 \pm 5.59$ years and the mean gestational time was $26.26 \pm 10.72$ weeks. Symptoms of RLS were seen in $46.4 \%$ of the women. The mean for the RLS Violence Rating Score was $20.82 \pm 6.61$ for the women with RLS. RLS was found to be mild in $5.2 \%$ of the women, moderate in $45.7 \%$, severe in $40.5 \%$ and very severe in $8.6 \%$. A statistically significant effect of RLS survival on quality of life was observed.

CONCLUSION: These results indicate that almost half of the pregnant women in this study experienced RLS, and about half of those with RLS experienced severe or very severe RLS. There is a significant relationship between RLS and six domains of SF-36 (physical, role limitations, pain, general health perception, energy/vitality, and mental health).

KEYWORDS: Restless legs syndrome. Quality of life. Pregnancy.

\section{INTRODUCTION}

Restless legs syndrome (RLS) is a sensory and motor disorder characterized by uncomfortable and unpleasant sensations which lead to a strong and irresistible urge to move one's leg and occur during periods of inactivity, generally during sleep. ${ }^{1}$ RLS prevalence has been reported to range from 2 to $15 \%{ }^{2,3} \mathrm{~A}$ community-based study found a RLS prevalence of $3.19 \%$ in Turkey. ${ }^{4}$

The prevalence of RLS increases with age and is two times more common in women than in men. ${ }^{3}$
The reason for this gender difference has not been explained accurately; however, it is considered that it may be due to hormonal changes during the periods of pregnancy, menstruation, and menopause. ${ }^{5}$ Minar et al. ${ }^{6}$ confirmed the relatively high prevalence of RLS in pregnant women compared with the general population. They found that more than 30\% of positive cases had clinically significant symptoms, and $50 \%$ reported sleep disturbances.

Pregnancy is reported as a significant risk fac-

DATE OF SUBMISSION: 28-Nov-2018

DATE OF ACCEPTANCE: 31-Dec-2018

CORRESPONDING AUTHOR: PInar Akbaş

Emniyet Mah. Muammer Yaşar Bostancı Cad. No:16 06560 Beşevler - Ankara - Turkey - 06500

E-mail: pnar.ates74@gmail.com 
tor which may precipitate and worsen RLS. ${ }^{7}$ RLS affects up to one-third of pregnant women, peaks in the third trimester and usually subsides after delivery ${ }^{6,8-10}$ History of RLS before conception, RLS during a previous pregnancy, coffee consumption before pregnancy, peptic ulcer disease, hemoglobin < $11 \mathrm{~g} / \mathrm{dl}$, and inadequate supplementation of iron and folate during pregnancy, particularly when there is iron deficiency, were found to be risk factors for the development of RLS during pregnancy. ${ }^{11,12}$ Hormonal factors are thought to play a role in the manifestation and development of RLS, especially during pregnancy. ${ }^{13}$ It has been suggested that high estradiol, increased prolactin and increased progesterone during pregnancy may trigger RLS. ${ }^{14}$ Thyroid hormone levels tend to rise during the third trimester. A negative relationship has been found between thyroid hormones and dopamine that indicates they can take part in the etiology of RLS. ${ }^{15}$ Thus, dietary and hormonal factors have been found to be associated with RLS during pregnancy.

The World Health Organization's (WHO) broad and multidimensional definition of quality of life (QoL) incorporates physical, psychological, social, and environmental aspects of life and emphasizes the individual, subjective appraisals. ${ }^{16}$ The construct of HRQoL enables the evaluation of how a health condition influences a person's perception of QoL. The concept assesses the impact of mental and physical health status on different areas in a person's life. ${ }^{17}$ Pregnancy is a process that creates significant anatomical, physiological, and biochemical changes in a woman's life. These changes affect the physical and emotional behaviors of women and can lead to decreased health-related quality of life. Moreover, some complications such as RLS can lead to decreased health-related quality of life in pregnancy. ${ }^{18}$ Individuals with RLS sometimes avoid participating in social activities and can experience chronic sleep disorders and psychiatric problems such as depression and anxiety disorders. Furthermore, Ramirez et al. ${ }^{19}$ showed a high possibility of pregnant women who had symptoms of RLS developing pre-eclampsia. Meharaban et al. ${ }^{13}$ reported that pregnancies complicated by RLS are at increased risk for preterm birth. It was found that compared to pregnant women without RLS, those with RLS were more likely to have poor sleep quality, poor daytime function, and excessive daytime sleepiness. ${ }^{20}$ Therefore, RLS has significant impacts on daily life and quality of life. Although
RLS is related to reduced quality of life and poor sleep in the general population, data on RLS-associated maternal sleep-wake disturbances are lacking. ${ }^{21}$ Prior reports have linked sleep-wake disturbances to adverse pregnancy and delivery outcomes (e.g., preterm delivery, prolonged labor, cesarean section deliveries, and postpartum depression). ${ }^{22}$ Terzi et al. ${ }^{23}$ found a significant difference between RLS and obstructive sleep apnea symptoms (witnessed apnea and fatigue) in pregnant women. In order to suggest solutions to the problems experienced by pregnant women, it is important to determine these problems and their effects on pregnancy during follow-up, care, and counseling services for pregnant women. There are studies in the literature regarding the increase in the frequency of RLS in the past ${ }^{8,10,24,25}$; but there are limited studies evaluating the relationship between RLS and quality of life. ${ }^{6,24,26,27}$ RLS is often underestimated and undiagnosed in pregnancy and can lead to a lower quality of life. Thus, it becomes significant to research RLS and its relationship with quality of life in pregnant women. The study findings will provide guidance for planning interventions to improve quality of life in pregnant women with RLS.

\section{METHODS}

\section{Purpose and Design of the Study}

This was a cross-sectional descriptive study that aimed to determine the extent of RLS in pregnant women and to evaluate its relationship with quality of life.

\section{Population and Sample of the Study}

The study population consisted of 2,900 pregnant women who applied to gynecology and obstetrics outpatient clinics in Karabük University Training and Research Hospital between 2015 and 2016. In order to determine the sample size, a power analysis was conducted (sample error: 0.01 and power: 95\%), and the prevalence of RLS was accepted as 19-26\% $\%$ The minimum number of people to be included in the study sample was calculated as 208. A total of 250 pregnant women were included in the study. In order to homogenize the sample group and remove as much as possible the factors that affect the quality of life outside the RLS, all women who were literate, had no chronic or psychiatric disease, did not have a high-risk pregnancy, and agreed to participate in the study were enrolled. 


\section{Data collection instruments}

The data were collected using a questionnaire form that was developed by the researcher based on a literature review. ${ }^{7,9,28}$ We evaluated the sociodemographic (9 questions) and pregnancy (5 questions) features of the participants. We administered the Short Form 36 (SF-36) Questionnaire to measure the quality of life, and the International Restless Legs Syndrome Study Group (IRLSSG) Diagnostic Criteria for RLS to evaluate the presence of RLS in all of the pregnant women. We then administered the Restless Legs Syndrome Rating Scale to the pregnant women who fulfilled diagnostic criteria for RLS.

IRLSSG Diagnostic Criteria for RLS: This questionnaire was developed in 1995 based on the experiences of patients and includes 5 questions. Patients who respond "yes" to all five questions are diagnosed with RLS. ${ }^{9}$ The reliability and validity study of the Turkish version of the questionnaire was conducted by Sevim et al. ${ }^{4}$, and Cronbach's alpha coefficient was above 0.81 for each item.

The Restless Legs Syndrome Rating Scale was developed by IRLSSG. ${ }^{9}$ It includes 10 items which are scored from none (score 0) to very severe (score 4). The minimum and maximum scores obtained on the scale are 0 and 40, respectively. The severity is classified as mild (score 0-10), moderate (score 11-20), severe (score 21-30), and very severe (score 31-40). The Turkish version of the scale was found valid and reliable and has been used in many studies in Turkey. ${ }^{2,28,29}$ In our study, Cronbach's alpha coefficient was 0.823 for the scale.

The Short Form-36 Health Survey Questionnaire (SF36 ) is one of the most frequently used instruments to measure the quality of life. It was developed and presented by Rand Corporation in $1992 .{ }^{28}$ The first version of the questionnaire used in the 1990s and was composed of 149 items. Then, the 20-item SF20 health survey was developed based on the results from more than 22,000 patients in studies, which loaded factor analyses. However, in order to enhance its extent and psychometric features, the number of items was increased to 36 , and the SF-36 was developed. This 36-item questionnaire measures quality of life across eight dimensions, which are physical functioning (10 items), role limitations due to physical problems (4 items), role limitations due to emotional problems (3 items), social functioning (2 items), mental health (5 items), energy/vitality (4 items), pain (2 items) and general health perception (5 items). ${ }^{28}$ It is completed in response to how the patients have felt in the last 4 weeks and scored on a Likert-type scale (3-6 Likert type), except for the 4th and 5th items, which are responded to with "yes" or "no". ${ }^{30}$ The questionnaire does not have a total score; however, each subscale has a total score, and the scores range from 0 to 100. A score of 100 indicates good health and a score of $O$ indicates poor health. ${ }^{28}$ The reliability and validity study of the Turkish version of SF-36 was conducted by Koçyiğit et al. ${ }^{30}$ with a Cronbach's alpha coefficient between 0.73 and 0.76. The SF-36 is used to measure the quality of life in pregnant women both in Turkey and across the world. ${ }^{31,32}$ In our study, Cronbach's alpha coefficient was found to range between 0.62 and 0.87 for the scale.

\section{Procedure}

The data collection instruments were administered to pregnant women in a face-to-face interview with the researcher. The data were collected in a calm environment in outpatient clinics, after or before the examination of the patient. It took approximately 20-25 minutes to complete the instruments per person. The questionnaire form, the SF-36, and the RLS criteria form were administered to all of the pregnant women. The RLS Rating Scale was administered only to the women fulfilling diagnostic criteria for RLS.

\section{Data Analysis}

The data were analyzed using SPSS 24.0 (Statistical Package for Social Sciences, version 24.0, for Windows) and values below $0.05(\mathrm{p}<0.05)$ were accepted as statistically significant. Normality of the data was tested by performing the Shapiro-Wilk test. The comparison of variables with a normal distribution was tested by performing multiple comparison tests and Student t-test to compare the means of two independent groups. The Student t-test was used to determine the statistical relationship between RLS living conditions and SF-36 quality of life scale scores, and RLS severity and SF-36 quality-of-life scale scores.

\section{Ethical Aspect of the Study}

Before data collection began, we obtained ethics approval from the General Secretariat of the Association of Public Hospitals in Karabük (reference number 88919140/604.99) and Gazi University Ethics Committee (reference number issue:77082166-302.08.01-E.15258, date: 30.12.2016), 
and written consent from the pregnant women participating in the study. The pregnant women who were identified as having RLS were referred to a neurologist.

\section{RESULTS}

The pregnant women's mean age was $28.11 \pm 5.59$ years; their mean gestation time was $26.26 \pm 10.72$ weeks. Among the women, $36.4 \%$ were between 18 25 years, $50.8 \%$ aged between $26-35$ years, $12.8 \%$ between 36-45 years, $30.8 \%$ graduated from high school, $82.8 \%$ were unemployed, $58.4 \%$ perceived their economic level as moderate and poor, and 77.2 $\%$ were living in a city.

In total, $46.4 \%$ of the pregnant women were found to meet diagnostic criteria for RLS, and among them, $5.2 \%$ had mild RLS, $45.7 \%$ had moderate RLS, $40.5 \%$ had severe RLS, and $8.6 \%$ had very severe RLS.

The mean scores of the participants for the SF-36 subscales were $58.04 \pm 23.35$ for physical functioning, $25.10 \pm 33.86$ for role limitations due to physical problems, $68.39 \pm 24.93$ for pain, $67.10 \pm 22.30$ for general health perception, $46.64 \pm 24.57$ for energy/ vitality, $64.20 \pm 27.93$ for social functioning, $49.20 \pm$ 39.20 for role limitations due to emotional problems and $77.52 \pm 19.73$ for mental health.
There were significant differences found in mean physical functioning, role limitations (physical), pain, general health perception, energy/vitality and mental health scores between the women with and without RLS $(p<0.05)$. The pregnant women with RLS had lower scores on physical functioning (50.09 $\pm 23.078)$, role limitations (physical) $(17.89 \pm 29.637)$, pain $(63.09 \pm 24.296)$, general health perception (63.97 \pm 22.552$)$, energy/vitality (38.75 \pm 20.683$)$ and mental health $(74.55 \pm 21.352)$ than those without RLS (Table 1).

There was a significant relationship between RLS severity and all SF-36 subscale scores, except the subscales "mental health" and "general health perception" ( $\mathrm{p}<0.005)$. The women with mild and moderate RLS had higher scores on the subscales physical functioning $(p=0.001)$, role limitations due to physical health $(p=0.002)$, pain $(p=0.001)$, energy/vitality $(p=$ $0.001)$, social functioning $(p=0.023)$ and role limitations due to emotional problems $(p=0.035)$ than those with severe and very severe RLS (Table 2).

\section{DISCUSSION}

RLS, which is common in society, is a condition that causes an urge to move one's legs and leads to restlessness in extremities. Prevalence of RLS is re-

TABLE 1. RELATIONSHIP BETWEEN RLS AND SF-36 SUBSCALE SCORES ( $N=250)$

\begin{tabular}{|c|c|c|c|c|c|c|c|c|}
\hline \multicolumn{9}{|c|}{ SF-36 Subscale Scores } \\
\hline & $\begin{array}{l}\text { Physical } \\
\text { Functioning }\end{array}$ & $\begin{array}{l}\text { Role } \\
\text { Limitations } \\
\text { (Physical) }\end{array}$ & Pain & $\begin{array}{l}\text { General } \\
\text { Health } \\
\text { Perception }\end{array}$ & $\begin{array}{l}\text { Vitality } \\
\text { (Energy) }\end{array}$ & $\begin{array}{l}\text { Social } \\
\text { Functioning }\end{array}$ & $\begin{array}{l}\text { Role } \\
\text { Limitations } \\
\text { (Emotional) }\end{array}$ & Mental Health \\
\hline With RLS (n=116) & $50.09 \pm 23.078$ & $17.89 \pm 29.637$ & $63.09 \pm 24.296$ & $63.97 \pm 22.552$ & $38.75 \pm 20.683$ & $62.07 \pm 26.679$ & $45.40 \pm 40.144$ & $74.55 \pm 21.352$ \\
\hline Without RLS ( $n=134)$ & $64.93 \pm 21.390$ & $31.34 \pm 36.103$ & $72.97 \pm 24.654$ & $69.81 \pm 21.808$ & $53.47 \pm 25.680$ & $66.04 \pm 28.947$ & $52.49 \pm 38.209$ & $80.09 \pm 17.905$ \\
\hline Statistics & $\begin{array}{l}\mathrm{t}:-5.273 \\
\mathrm{p}: 0.001^{\star}\end{array}$ & $\begin{array}{l}\mathrm{t}:-3.235 \\
\mathrm{p}: 0.001^{*}\end{array}$ & $\begin{array}{l}\mathrm{t}:-3.180 \\
\mathrm{p}: 0.002^{*}\end{array}$ & $\begin{array}{l}\mathrm{t}:-2.079 \\
\mathrm{p}: 0.039^{\star}\end{array}$ & $\begin{array}{l}\mathrm{t}:-5.107 \\
\mathrm{p}: 0.001^{\star}\end{array}$ & $\begin{array}{l}\mathrm{t}:-1.123 \\
\mathrm{p}: 0.263\end{array}$ & $\begin{array}{l}\mathrm{t}:-1.428 \\
\mathrm{p}: 0.154\end{array}$ & $\begin{array}{l}\mathrm{t}:-2.230 \\
\mathrm{p}: 0.027^{\star}\end{array}$ \\
\hline
\end{tabular}

$\mathrm{P}<0.005,{ }^{\star}$ Student $\mathrm{t}-\mathrm{Test}$

TABLE 2. CORRELATION BETWEEN RLS SEVERITY AND SF-36 SUBSCALE SCORES OF PREGNANT WOMEN WITH RLS (N=116)

\begin{tabular}{|c|c|c|c|c|c|c|c|c|}
\hline \multicolumn{9}{|c|}{ SF-36 Subscale Scores } \\
\hline & $\begin{array}{l}\text { Physical } \\
\text { Functioning }\end{array}$ & $\begin{array}{l}\text { Role } \\
\text { Limitations } \\
\text { (Physical) }\end{array}$ & Pain & $\begin{array}{l}\text { General } \\
\text { Health } \\
\text { Perception }\end{array}$ & $\begin{array}{l}\text { Vitality } \\
\text { (Energy) }\end{array}$ & $\begin{array}{l}\text { Social } \\
\text { Functioning }\end{array}$ & $\begin{array}{l}\text { Role } \\
\text { Limitations } \\
\text { (Emotional) }\end{array}$ & Mental Health \\
\hline $\begin{array}{l}\text { Mild and Moderate } \\
(n=59)\end{array}$ & $58.47 \pm 21.36$ & $\begin{array}{l}26.27 \pm \\
33.93\end{array}$ & $73.63 \pm 21.17$ & $67.46 \pm 18.48$ & $45.76 \pm 19.23$ & $67.58 \pm 23.69$ & $53.11 \pm 36.68$ & $77.49 \pm 18.54$ \\
\hline $\begin{array}{l}\text { Severe and Very Severe } \\
(n=57)\end{array}$ & $41.4 \pm 21.69$ & $9.21 \pm 21.46$ & $52.19 \pm 22.58$ & $60.35 \pm 25.78$ & $31.49 \pm 19.75$ & $\begin{array}{l}56.36 \pm \\
28.56\end{array}$ & $37.43 \pm 42.29$ & $71.51 \pm 23.70$ \\
\hline Statistics & $\begin{array}{l}\mathrm{t}: 4.271 \\
\mathrm{p}: 0.001^{*}\end{array}$ & $\begin{array}{l}\mathrm{t}: 3.248 \\
\mathrm{p}: 0.002^{\star}\end{array}$ & $\begin{array}{l}\text { t: } 5.275 \\
p: 0.001^{*}\end{array}$ & $\begin{array}{l}\mathrm{t}: 1.701 \\
\mathrm{p}: 0.092\end{array}$ & $\begin{array}{l}\mathrm{t}: 3.943 \\
\mathrm{p}: 0.001^{*}\end{array}$ & $\begin{array}{l}\mathrm{t}: 2.308 \\
\mathrm{p}: 0.023^{*}\end{array}$ & $\begin{array}{l}\mathrm{t}: 2.135 \\
\mathrm{p}: 0.035^{\star}\end{array}$ & $\begin{array}{l}\mathrm{t}: 1.511 \\
\mathrm{p}: 0.134\end{array}$ \\
\hline
\end{tabular}

P<0.005. *Student T-Test 
ported at about $10 \%$ in the general population ${ }^{33}$ and $11-26 \%$ in pregnant women. ${ }^{8,10}$ Yüksel et al. ${ }^{9}$ found a prevalence of RLS of $44.6 \%$ among pregnant women in their study. In our study, the RLS prevalence was found to be $46.4 \%$ for the pregnant women; thus, results in our study are higher than the RLS rates seen among pregnant women in the general population. Similarly, Telarovic et al. ${ }^{24}$ reported that the frequency of RLS was found to be significantly higher in pregnant women when compared to non-pregnant women. The RLS prevalence in pregnancy has been reported between 10 and 34\% worldwide in the literature. ${ }^{6,25,34}$ It is reported that RLS affects up to onethird of pregnant women, peaks in the third trimester, and usually subsides after delivery. ${ }^{6}$ However, in a study conducted with 231 pregnant women by Meharaban et al. ${ }^{13}$, the prevalence was found to be 47.3 $\%$ for RLS. The results of our study are consistent with the literature. Our study has revealed that almost half of pregnant women experience RLS during pregnancy.

When assessing RLS severity, we found that the women's mean RLS severity score was $20.82 \pm 6.61$, and $49.1 \%$ of these women experienced severe or very severe RLS. In a previous study, $53.5 \%$ of pregnant women were reported to have severe and very severe RLS, ${ }^{35}$ and in another, $74.7 \%$ were reported to have moderate RLS. ${ }^{25}$ Minar et al. ${ }^{6}$ found that more than $30 \%$ of positive cases had clinically significant symptoms. Our study findings are similar to the literature in Turkey and worldwide, revealing that about half of pregnant women experience RLS and that half of these cases are severe. When the negative effects created by RLS in pregnancy (poor sleep quality, poor daytime function, excessive daytime sleepiness, pre-eclampsia, preterm birth) and adverse effects of sleep problems created by the RLS (preterm delivery, prolonged labor, cesarean section deliveries, and postpartum depression) are considered, the necessity of screening pregnant women in Turkey for RLS becomes clear. ${ }^{13,19,20,22}$

RLS is often underestimated and undiagnosed in pregnancy and can lead to a lower quality of life. It is commonly associated with pregnancy, and its symptoms negatively impact the quality of life in pregnant women. ${ }^{6}$ Sleep disturbance, tiredness during the day ${ }^{34,36}$, leg cramps and anxiety due to RLS ${ }^{13,37}$ may impair quality of life among individuals with RLS. Studies have shown that the use of estrogen for reducing sleep problems is effective in $\operatorname{RLS}^{38,39}$. Howev- er, the use of estrogen is not favorable in pregnancy. In our study, statistically significant differences were found between the women with and without RLS in the mean scores of the subscales (physical functioning, role limitations (physical), pain, general health perception, energy/vitality, and mental health) of the SF-36 scale $(p<0.05)$. Pregnant women with RLS were found to have a poorer quality of life compared to those without RLS with regard to these subscales. In addition, we found a significant relationship between RLS severity and all SF-36 subscale scores, except subacalesfor "mental health" and "general health perception" $(p<0.005)$. Pregnant women with mild and moderate RLS scored higher on the subscales of physical functioning, role limitations due to physical health, pain, energy/vitality, social functioning, and role limitations due to emotional problems than those with severe and very severe RLS. Similarly, Telarovic et al. ${ }^{24}$ reported that analysis of different variables determining QoS and quality of life showed consistently significantly lower values for the group of RLS-positive pregnant women compared to pregnant women without neurological disorders. Allen et al. ${ }^{21}$ stated in their population-based study that quality of life of among people with RLS was affected in all domains of the SF-36 scale. In another study with women of reproductive age, Güzel et al. ${ }^{28}$ found that women with RLS scored lower on all SF-36 subscales than those without RLS, and these women with RLS had a poor quality of life. Similarly, Ghanei- Gheshlagh et al. ${ }^{27}$ reported that quality of life in women with restless legs syndrome was lower than in healthy pregnant women. Our findings are consistent with the literature. All in all, it is considered that RLS and the severity of symptoms negatively affect the quality of life in pregnant women.

\section{Strength and Limitations}

This is the first study carried out to explore the relationship between RLS and quality of life in pregnant women in Turkey and is considered to be a guide for further studies. Nevertheless, it has some limitations which include the following: (1) The population is limited, so the results can only be generalized to this population; (2) The data were based on self-reporting of the pregnant women, and not observed by the researcher; and (3) Laboratory tests or imaging studies were not used to evaluate RLS in the pregnant women; and (4) Quality of life is a complex structure influenced by socioeconomic factors. Although there is a 
statistically significant association between RLS and quality of life, quality of life may be affected by other factors associated with pregnancy. The fact that the changes in pregnancy cannot be excluded as a source of impaired quality of life is among the limitations of this study.

\section{CONCLUSIONS}

These results indicate that almost half of the pregnant women studied experience RLS and about half of those experience severe or very severe RLS. The women's quality of life is poor regarding role limitations due to physical health and is moderate regarding other subscales. There is a significant relationship between RLS and six domains of the SF36 (physical functioning, role limitations [physical], pain, general health perception, energy/vitality, and mental health). Therefore, pregnant women with RLS have a poorer quality of life compared to those without RLS, regarding these domains. Additionally, there is a negative correlation between RLS severity and all SF-36 subscales, except for "mental health" and "general health perception," which indicates that an increase in RLS severity is accompanied by a decrease in quality of life.

Based on these findings, we recommend that regular monitoring of pregnancy should include an evaluation for RLS. Health professionals should plan interventions to improve quality of life in pregnant women with RLS (such as smoking cessation, nutrition education, sleep hygiene), and further studies should be carried out to investigate the relationship between RLS and quality of life with larger sample size and in different groups.

\section{Acknowledgments}

We gratefully thank Sultan Özkan Şat for her help in this study and the pregnant women who participated in this study.

\section{RESUMO}

OBJETIVO: Neste estudo, objetivamos determinar a extensão da síndrome das pernas inquietas (SPI) em gestantes e avaliar a relação da síndrome com a qualidade de vida.

MÉTODOS: Este é um estudo descritivo transversal. Um questionário desenvolvido pelo pesquisador, o Questionário Short Form 36 (SF36) para medir a qualidade de vida, o Grupo Internacional de Síndrome das Pernas Inquietas (IRLSSG) Critérios de Diagnóstico para SPI e a Escala de Avaliação da Síndrome das Pernas Inquietas foram administrados às mulheres para coletar os dados. Um total de 250 gestantes foi incluído no estudo.

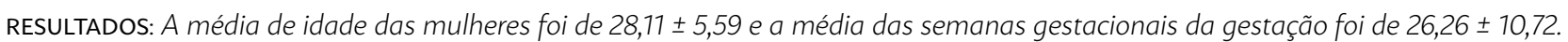
Os sintomas da SPI foram observados em 46,4\% das mulheres. A média para o Índice de Violência da RLS foi de 20,82 $\pm 6,61$ para as mulheres com SPI. A SPI foi discreta em 5,2\% das mulheres, moderada em 45,7\%, grave em 40,5\% e muito grave em 8,6\%. Um efeito estatisticamente significativo da sobrevida da SPI na qualidade de vida foi observado $(p<0,005)$.

CONCLUSÃO: Estes resultados indicam que quase metade das mulheres grávidas neste estudo experimentou a SPI, e cerca de metade das pessoas com SPI experimentou SPI grave ou muito grave. Existe uma relação significativa entre a SPI e seis domínios do SF-36 (físico, limitação de papéis, dor, percepção geral de saúde, energia/vitalidade e saúde mental).

PALAVRAS-CHAVE: Síndrome das pernas inquietas. Qualidade de vida. Gravidez.

\section{REFERENCES}

1. Tekdöş Demircioğlu D, Kavadar G, Esen Öre Ö, Emre T, Yaka U. Relationship between restless legs syndrome and quality of life in uremic patients. Agri. 2015;27(2):73-8

2. Bilgilisoy FM, Çakır T. Güncel tanı kriterleri ile huzursuz bacak sendromu. Türk Osteoporoz Dergisi. 2015; 21:87-95.

3. Merlino G, Valente M, Serafini A, Gigli GL. Restless legs syndrome: diagnosis, epidemiology, classification and consequences. Neurol Sci. 2007;28(Suppl 1):S37-46.

4. Sevim S, Dogu O, Camdeviren H, Bugdayci R, Sasmaz T, Kaleagasi H, et al. Unexpectedly low prevalence and unusual characteristics of RLS in Mersin, Turkey. Neurology. 2003;61(11):1562-9.

5. Ghorayeb I, Bioulac B, Scribans C. Tison F. Perceived severity of restless legs syndrome across the female life cycle. Sleep Med. 2008;9(7):799-802.

6. Minar M, Habanova H, Rusnak I, Planck K, Valkovic P. Prevalence and impact of restless legs syndrome in pregnancy. Neuro Endocrinol Lett. 2013;34(5):366-71.
7. Çakmak B, Metin Z, Karataş A, Özsoy Z, Demirtürk F. Gebelikte huzursuz bacak sendromu. Perinatoloji Dergisi. 2014; 22(1):1-5.

8. Sahin F, Köken G, Coşar E, Solak E, Saylan F, Fidan F, et al. Gebelerde huzursuz bacak sendromu sıklığ. Türk Jinekoloji ve Obstetrik Dergisi Derneği. 2007;4(4):246-9.

9. Yüksel B, Seven A, Yıldız Y, Kucur S, Gözükara İ, Polat M, et al. Gebelikte huzursuz bacak sendromu. Jinekoloji-Obstetrik ve Neonatoloji Tıp Dergisi. 2015;12(4):144-6.

10. Tunç T, Karadağ YS, Doğulu F, Inan LA. Predisposing factors of restless legs syndrome in pregnancy. Mov Disord. 2007;22(5):627-31.

11. Gupta R, Dhyani M, Kendzerska T, Pandi-Perumal SR, BaHammam AS, Srivanitchapoom P, et al. Restless legs syndrome and pregnancy: prevalence, possible pathophysiological mechanisms and treatment. Acta Neurol Scand. 2016;133(5):320-9.

12. Chen $\mathrm{PH}$, Liou $\mathrm{KC}$, Chen $\mathrm{CP}$, Cheng $\mathrm{S}$. Risk factors and prevalence rate 
of restless legs syndrome among pregnant women in Taiwan. Sleep Med. 2012;13(9):1153-7.

13. Meharaban Z, Yahya S, Sadegniiat K. Restless legs syndrome during pregnancy and preterm birth in women referred to realth centers of Ardabil. Iran Red Crescent Med J. 2015;17(12):e24438.

14. Dzaja A, Wehrle R, Lancel $M$, Pollmächer T. Elevated estradiol plasma levels in women with restless legs during pregnancy. Sleep. 2009;32(2):16974.

15. Pereira JC Jr, Pradella-Hallinan M, Lins Pessoa $\mathrm{H}$. Imbalance between thyroid hormones and the dopaminergic system might be central to the pathophysiology of restless legs syndrome a hypothesis. Clinics (Sao Paulo). 2010;65(5):548-54.

16. The Whogol Group. The World Health Organization Quality of Life Assessment (WHOQOL): development and general psychometric properties. Soc Sci Med. 1998;46(12):1569-85.

17. Beck CA, Shah S. Research on health-related quality of life and cardiac conditions. Home Healthc Nurse. 2012;30(1):54-60.

18. Costa D, Dritsa M, Verreault N, Balaa C, Kudzman |, Khalifé S. Sleep problems and depressed mood negatively impact health-related quality of life during pregnancy. Arch Womens Ment Health. 2010;13(3):249-57.

19. Ramirez JO, Cabrera SA, Hidalgo H, Cabrera SG, Linnebank M, Bassetti $\mathrm{CL}$, et al. Is preeclampsia associated with restless legs syndrome? Sleep Med. 2013; 14(9):894-6.

20. Dunietz GL, Lisabeth LD, Shedden K, Shamim-Uzzaman QA, Bullough AS, Chames MC, et al. Restless legs syndrome and sleep-wake disturbances in pregnancy. J Clin Sleep Med. 2017; 3(7):863-70.

21. Allen RP, Walters AS, Montplaisir J, Hening W, Myers A, Bell TJ, et al. Restless legs syndrome prevalence and impact: REST general population study. Arch Intern Med. 2005;165(11):1286-92.

22. Dolatian M, Mehraban Z, Sadeghniat K. The effect of impaired sleep on preterm labour. West Indian Med J. 2014;63(1):62-7.

23. Terzi H, Terzi R, Zeybek R, Ergenoglu M, Hacivelioglu S, Akdemir A, et al. Restless legs syndrome is related to obstructive sleep apnea symptoms during pregnancy. Sleep Breath. 2015;19(1):73-8.

24. Telarovic S, Condic L, Telarovic I. Restless legs syndrome in pregnancy: frequency and impact on quality of life and sleep. Mov Disord. 2017;32(suppl 2):111.

25. Vahdat M, Sariri E, Miri S, Rohani M, Kashanian M, Sabet A, et al. Prevelance and associated features of restless legs syndrome in a pop- ulation of Iranian women during pregnancy. Int J Gynaecol Obstet. 2013;123(1):46-9

26. Chen SJ, Shi L, Bao YP, Sun YK, Lin X, Que JY, et al. Prevalence of restless legs syndrome during pregnacy: a systematic review and meta-analysis. Sleep Med Rev. 2017;40:43-54.

27. Ghanei-Gheshlagh R, Toloeipoor-Lanjavani T, Lazari N, Moslemi B. Comparison of the quality of life in pregnant women with and without restless legs syndrome. J Clin Nurs Midwif. 2014;3(1):54-61.

28. Güzel S, Kurtcebe Z, Şencan S, Turhan N. Doğurganlık Çağındaki kadınlarda hormonal değişikliklerin huzursuz bacak sendromu şiddeti, uyku ve yaşam kalitesi üzerine etkisi. Türkiye Fiziksel Tıp Rehabilitasyon Dergisi. 2013;59(1):45-51.

29. Gökçal E, Tamer S, Kiremitçi Ö. Hastane çalışanlarında huzursuz bacak sendromu sıklığı ve yaşam, uyku kalitesi üzerine etkisi. Van Tıp Dergisi. 2015;22(4):260-5.

30. Koçyiğit H, Aydemir Ö, Ölmez N. Kısa form 36 (KF-36)'nın Türkçe versiyonu güvenirliği ve geçerliliği. İlaç ve Tedavi Dergisi. 1999;12:102-6.

31. Hueston WJ, Kasik-Miller S. Changes in functional health status during normal pregnancy. J Fam Pract. 1998;47(3):209-12.

32. Taşdemir S, Balci E, Günay O. Comparison of life quality of pregnant adolescents with that of pregnant adults in Turkey. Ups J Med Sci. 2010;115(4):275-81.

33. Bayard M, Avonda T, Wadzinski . Restless legs syndrome. Am Fam Physician. 2008;78(2):235-40

34. Neau IP, Porcheron A, Mathis S, Julian A, Meurice IC, Paquerau I, et al. Restless legs syndrome and pregnancy: a questionnaire study in the Poitiers District, France. Eur Neurol. 2010;64(5):268-74

35. Alves DA, Carvalho LB, Morais JF, Prado GF. Restless legs syndrome during pregnancy in Brazilian women. Sleep Med. 2010;11(10):1049-54.

36. Cuellar NG, Strumpf NE, Ratcliffe S). Symptoms of restless legs syndrome in older adults: outcomes on sleep quality, sleepiness, fatigue, depression and quality of life. J Am Ger Soc. 2007;55(9):1387-92.

37. Gamaldo CE, Earley C). Restless legs syndrome: a clinical update. Chest. 2006;130(5):1596-604.

38. Hachul H, Baracat EC, Soares JM Jr, Haidar MA, Mello MT, Tufik S, et al. Estrogen therapy reduces nocturnal periodic limb movements. Maturitas. 2007;58(3):319-22.

39. Hachul H, Bittencourt LR, Soares IM Jr, Tufik S, Baracat EC. Sleep in post-menopausal women: differences between early and late post-menopause. Eur J Obstet Gynecol Reprod Biol. 2009;145(1):81-4. 